INTERNATIONAL JOURNAL OF MULTIDISCIPLINARY RESEARCH AND ANALYSis

ISSN(print): 2643-9840, ISSN(online): 2643-9875

Volume 04 Issue 10 October 2021

DOI: 10.47191/ijmra/v4-i10-01, Impact Factor: 6.072

Page No.- 1349-1352

\title{
Mingtepa Monument in Archaeological Research
}

\author{
Turdikhujaeva Makhliyokxon Muqimkxuja qizi \\ Tashkent State University of Oriental Studies teacher-intern
}

ANNOTATION: The article presents the historical issues of the Mingtepa archaeological monument, which is famous in the Fergana Valley. The archaeological study of Mingtepa as well as the scientific analysis of the various archaeological and historian's works on the solution of the archaeological problems of the Fergana Valley will be carried out. Also, in the article, opinions are expressed about the studies that have a special place in the historiography of this archaeological research. In the process of analyzing the historiography of Mingtepa archeology, an attempt was also made to cover the issue of the ancient capital of David. In addition, the data from the research archaeologists who studied this monument are comparative-analyzed, as well as the conclusions of the historiography. The results and prospects of the joint archaeological research carried out by Chinese-Uzbek archaeologists in the territory of Mingtepa today are summarized, and the scientific achievements of these expeditions are observed.

KEYWORDS: Fergana Valley, archeology, Mingtepa, blessing, ancient throne, archaeological historiography, archaeological expedition, great Fergana canal, M. E. Masson, Chju Yanshi, Anorboev, Matboboyev, "information on the history of Fergana", Journal of Vodiynoma.

\section{INTRODUCTION}

Archaeological research has been carried out since 1939 in the eastern part of Andijan region, at the Mingtepa archaeological monument, which is now in the center of the District of Blessing. Until now, this monument has been studied by several historians, archaeologists. In the same archaeological study of Mingtepa, first Masson and then A.N.Bernshtam[4:12], Yu.A.Zadneprovsky[13:25], partly V.I.Kozenkova[14:60], B.X.Zire" Lost In Test Match M.Abdullaeva[5:57-60] can be recognized separately. In addition, the service of the Uzbek-Chinese expedition in the archaeological study of this monument can be overemphasized. We can only meet individual works that have analyzed the archaeological monument in terms of historiography among general studies. In this article, we will try to reveal exactly the archaeological historiography aspects and analysis of Mıngtepa.

\section{MAIN PART}

For the first time the monument was erected in 1939 in connection with the construction of the Great Fergana canal, professor M. E. The archaeological expedition concluded under the leadership of Masson was involved. In general, the main impetus for the archaeological study of the valley is also the construction of this great Fergana canal. In 1946-th year Leningrad professor A.N Bernshtam began to seriously deal with Mingtepa. In 1946-1947 during the careful study of the city of Fergana A. N. Bernshtam identified the capital of the ancient State of Davan in Fergana - the city of Ershy. Natanovich chief a group of scientists came to the conclusion that the place of the city of Ershy is the place of Mingtepa, which is located next to the city of blessing in the Andijan region. Here is the first dig works A. N. It was carried out by the expedition of bernshtam in 1950-th year. According to the results of the work, three periods in the history of the Blessing were determined: [2:8-14]

The period of the appearance of the late Davan - city BC. At the end of the III-II Centuries.

Kushon, $\mathrm{m}$, I-mile I-III centuries the period of the flowering of the city and the reconstruction of the fortress after its destruction by the Khan's troops.

In the Middle Ages, in the VII-IX centuries, life was concentrated in the southern part of the city. 


\section{Mingtepa Monument in Archaeological Research}

Conducted excavations, A. N. As Bernshtam believes, archaeological grounds for the identification of the city of blessing - Ershi-were identified. Partly because the results of the work in 1950-th year were not published, it was not possible to understand the history of its layered construction at that time[12:140-155].

Bernshtam was shocked, the doctor of historical sciences Yu. A. Zadneprovsky is also a researcher who made his own conclusions on the Mingtepa archeology. He noted that this monument was left by the participants of the Bernshtam expedition as the largest ancient structure in terms of area across the entire valley. In 1973, Yuri Zadneprovsky conducted non-large controlled excavations in Mingtepa[12:140-155]. They were aimed at clarifying the issues of stratigraphy and the composition of the ceramic complex and are significant with the accumulation of important materials. This excavation work was carried out at two points. Excavation area $40 \mathrm{sq} . \mathrm{m}$ was held in the eastern part of the city. During the search, ovens, ceramic items were identified. On the hill in the center of the village are identified layers with a thickness of $5 \mathrm{~m}$. The collected materials allow us to create a more accurate picture of the ceramic complex. The emergence of groundwater was the reason for the cessation of work. Together with Zadneprovsky's Matboboyev, the 1991 scientific article published in the IMKY Journal "Goroditshe Markhamat " serves as an important resource in the study of Mingtepa archeology. It contains an analysis of archaeological expeditions and excavation works carried out in the territory of Mingtepa, and the archaeological studies of 1950, 1987 and their results are from this article. The stratigraphic observations and the citation of the results of the pottery analysis are one of the achievements of the article.

Prominent archaeologist Bakijan Matboboyev in the archaeological research of mingtepe is distinguished by his fruitful work. The author of several scientific articles on this subject has a key role in the archaeological study of the city of blessing. Verification work in this area is carried out in 1986 by the Department of FA Andijan blessing of B.X. It was started by under the leadership of Matbabaev. This work was chosen mainly for excavation work on the Western defensive wall, 12-13-14 - minors. As an achievement of this excavation process, we can emphasize the fact that in the process of cleaning the fortress and fortress walls, ceramics with a red pattern, as well as painted dishes with a pattern, will be found. In addition, in the northern part of the excavation was found an area of 1,6-1,8 $\mathrm{m}$ in height, and on the floor in it a rectangular furnace was dug in the size of $46 \times 27 \mathrm{CM}$. It is noteworthy that ceramics with a red pattern are found in all cultural layers. Please note that at this stage of the study of the pottery complex, there are ceramic pots with a crocheted pattern and a bowl with a bent part are much less. Even in 1987, together with the expedition of the chief Fergana of Zadneprovsky, archaeological work was continued by Matboboyev[12:140155].

The work carried out in 1986-1987 allowed to identify several building blocks in the fortress. For example, the upper, completely destroyed, from which only the parts of the upper platform were preserved, the remains of construction of at least 5 rooms with three ovens in the excavation punk (according to observations from 1986 year), the southern side of the ARC room site were found. This includes cultural layers dating back to the II period according to data from the southern slope of the Hill, etc. As a result of these archaeological investigations, it can be concluded that the discovery of a bottom platform about five meters thick indicates the presence of a monumental structure in the fortress, the status of the city of ancient Marhamat. For the first time in Fergana, a platform of such a size and complex structure was invented. And the finding of traces from the bricks on the foundation of this platform is of interest. They were found in blessing for the first time. The tradition of imprinting on this brick was a tradition in antiquity. And the opening of the Ark is an archaeological innovation.

In the article "Mingtepa: archaeological excavations and their analysis "of the Journal "Matbobayev Vadiynoma" in 2019 Year 3, the analysis and results of archaeological excavations in Mingtepa will be discussed separately. The author cites that the wall in Mingtepa is the first antiquity-built wall in the Fergana Valley[5:57].

In an article titled "Mingtepa - the ancient capital of Fergana", the author writes that the remains of Ershi - the "middle city", as reported by Chinese sources, were preserved only in Mingtepa (the area is more than 40 hectares), and the "middle city" is surrounded by two strong defensive walls, which are recorded archeologically. The defensive structures of the inner city were fully preserved: according to the data from 1952 year, 20 units were preserved on the western and eastern wall, 6 units in the south, 12 observation minarets (towers) in the North and reached us, says the professor(Matbobayev and Elmurod Ermatov were taken from the conversation on the topic that Mingtepa could become another historical museum under the open sky. 2017).

According to Matboboyev, after his lectures at the University of the city of Sian of the Republic of China in 2013 about Mingtepa, which was one of the more than 70 cities in the ancient times in the Fergana Valley, the interests of Chinese colleagues expressed their desire to further increase and cooperate after this lecture. If Uzbek archaeologists are well acquainted with the studies of the city on the ground, Chinese archaeologists are strong about its underground excavations. Therefore, the parties managed to achieve such satisfactory results. 


\section{Mingtepa Monument in Archaeological Research}

\section{RESULTS AND DISCUSSIONS}

In 2011, Uzbek and Chinese Academies of Sciences signed a cooperation agreement to organize a five-year archaeological expedition on the study of ancient Mingtepa. Since 2012, the cooperation of scientists of the two countries has been continuing. We know that this expedition was widely recognized that the capital of the country of David (Davan) in the Fergana Valley region in the VI-V centuries BC mingtepa was named after Ershi. They proved that more than 2000 years ago Mingtepa was the largest full-fledged fortress-city in the Fergana Valley.

If we pay attention to the potential of the city of Mingtepa and the situation preserved until today, according to the results of archaeological excavations carried out by the Institute of Social Sciences of the people's Republic of China Academy of Sciences of the Republic of Uzbekistan and the Institute of Archeology of the Academy of Sciences of the Republic of Uzbekistan The cultural layer of the central hill inside the fortress is $10 \mathrm{~m}$ more than. The lowest layer dates back to the IV century BC. Here the hill with the city arch is preserved. Mingtepa defense wall every $38-40 \mathrm{~m}$. in the distance, the observation tower is installed, its length is $18 \mathrm{~m}$. weight $9 \mathrm{~m}$, height 5-6 m.ga enough. Findings: stone slabs, a manufacturing enterprise, pits of different sizes, stone, ceramic, bone remains, even found a piece of ceramic with a picture of a warrior and a horse on one side, a horse on the other, or a deer on the other. Ceramic dishes are prepared elegant, with a high taste, and some are decorated with crocheted flowers. The skill the pictures put into the findings. "The picture with such a composition was found for the first time in the Valley ceramics," says the head of the Uzbek-Chinese international expedition, doctor of historical sciences, professor of the Institute of Archeology of the Academy of Sciences of Uzbekistan about us.

The work, which was published in 2018 under the name "Kohna and Mingtepa" (from ancient Fergana history) by Doctor of historical sciences, clever Orientalist scientist Mahmudjon Hasani Obidjan Mahmud Dovoni, has been devoted to the history of Mingtepa, reflecting the historical-toponomical and ethnographic landscapes of Mingtepa ( Suja team. Archaeological survey and excavation of the mingtepa site in andijan region, uzbekistan sino-uzbek joint archaeological team $31 \mathrm{dec} 2019$ ). The book also contains information about the entire history of Mingtepa, archaeological monuments, cultural heritage. The map that reflects the high historical-archaeological Mingtepa land listed in the book is perfect. In this book, archaeological data are enough. Ablat Khujayev opposes the idea that in the nominative part of his book" information on the history of Ferghana", where exactly is Ershi, this is the capital, and interprets his opinion through Chinese sources[11:97].

On the issue of Mingtepa, the army also conducted research in the Kyrgyz Republic. Although they were not dedicated exactly to the millennium, they touched on this in the light of the issues of the ancient capital of David in the issue of the ancient throne. For example, Kadicha Toshboyeva in a large article "O stolise Matbabaev, A.Anarbayev, A.The husband of the khodzhaevs brings his thoughts on the issue of which city he is now in and expresses his attitude to him. Tashboyeva criticizes Khujayev's opinion that Ershi Dovon is one of the 70 cities, the capital of which can be, because it is an ordinary city. According to the author, Ershi was not mentioned so much in Chinese chronicles when there was no city in the status of the capital, and the desire to walk here would not have been in China either. In our opinion, Ershi was not an ordinary city. Because in Chinese sources it is clearly said that in Ershida there was a council of elders. Researcher Zadneprovsky, Bernshtam, Matboboyev also came up with in his article that the ancient Ershi stated that this is the present blessing, namely Mingtepa[2:8].

\section{CONCLUSION}

As a result of our research, we can say that this issue has not been overlooked by Tajik researchers either. For example, in the scientific article of Ayubov Abdusator Raufovich titled. In conclusion, despite the fact that the Mingtepa archaeological monument has been studied for some time in terms of historiography, this monument is still full of many contradictions, confusion in archaeological research. In particular, the issue of its capital status has not yet been clearly resolved. Theorical on the issue of publications, most of the scientific research on this monument is published in foreign journals, while in Uzbeklanguage archeology journals it is rare. And this leads to the fact that the young researcher devotes himself to the study of historians.

\section{REFERENCE}

1) Ablat Khujaev information on the history of Fergana. Fergana-2013.240 $p$.

2) Ayubov.A. R. Issues of toponymy and localization of the capital cities of Ferghana in Chinese sources and in modern historiography / / VESTNIK TSUPBP. Khuzhand-2019. No. 1. P. 8-14.

3) Askarov.A. Travel Guide to marxdmat / / "history of Turon" Toshkent, 2010. № 4. p 6-10.

4) Bernshtam A. N. Historical and archaeological essays of the Central Tien Shan and Pamir-Alai. M.; L., 1952129 p.

5) Matboboev B. Mingtepa: archaeological excavations and their analysis. Valley A 2019 №3 (14) p.57-60. 


\section{Mingtepa Monument in Archaeological Research}

6) Matbabaev B. H. et al. The report of the Uzbek-Chinese joint archaeological expedition on the work done at the Mingtepa settlement in 2012. - Samarkand, $2013210 \mathrm{p}$

7) Matbabaev B. Kh., Mashrabov Z. Z. Ancient and medieval Andijan (historical and archaeological research). T-2011p

8) Matboboev B.X., Ummatov A. Ancient unique fine art work found in mingtepe / / material-spiritual heritage and universal values. Collection of scientific articles. T-2019.

9) About us B.X. Mashrabov Z.Z. History of Andijan (from ancient times to the beginning of XX century) Tashkent 2014. $210 \mathrm{p}$.

10) Obidjon Mahmud Dovoni " ancient and eternal Mingtepa (from ancient Fergana history) T-2019. 178 p.

11) Tashbaeva K. On the problem of localization of the cities of the state of Davan / / Civilizations of pastoralists and farmers of Central Asia. - Samarkand-Bishkek, 2005.97 p.

12) Zadneprovsky Yu. A., Matbabaev B. H. The settlement of Marhamat (some results of the study) / / IMKU. Issue 25. T1991 With 140-155.

13) Zadneprovsky Yu. A. Druzhinina E. V. Works of the Ferghana expedition //Archaeological discoveries of 1973, Moscow1974. P. 480-487.

14) Kozenkova V. I. Archaeological works in the Andijan region in 1956 / / Brief reports of the Institute of the History of Material Culture.1959. Issue 76. P. 60-76.

15) Jalilov S. Andijan. Historical-local history - Tashkent: Uzbekistan, 1989. 180 p. 